Winter 2010

\title{
East Asian Order Formation and Sino-Japanese Relations
}

Men Honghua

Party School of CPC Central Committee, China

Follow this and additional works at: https://www.repository.law.indiana.edu/ijgls

Part of the International Law Commons, and the Law and Politics Commons

\section{Recommended Citation}

Honghua, Men (2010) "East Asian Order Formation and Sino-Japanese Relations," Indiana Journal of Global Legal Studies: Vol. 17 : Iss. 1 , Article 4.

Available at: https://www.repository.law.indiana.edu/ijgls/vol17/iss1/4

This Symposium is brought to you for free and open access by the Law School Journals at Digital Repository @ Maurer Law. It has been accepted for inclusion in Indiana Journal of Global Legal Studies by an authorized editor of Digital Repository @ Maurer Law. For more information, please contact rvaughan@indiana.edu.

\section{$\Psi$}

JEROME HALL LAW LIBRARY

INDIANA UNIVERSITY

Maurer School of Law
Bloomington 


\title{
East Asian Order Formation and Sino-Japanese Relations
}

\author{
MEN HONGHUA *
}

\section{INTRODUCTION}

East Asia is now widely regarded as the focus of the world's attention. ${ }^{1}$ Since the end of the Cold War, East Asia has entered into an era of comprehensive engagements, triggered in particular by China's constructive and peaceful rise and the region's reply to the challenge of the Asian financial crisis in the late 1990s. The security, political, and economic maps of East Asia have been transformed, and an institutionalized framework for regional cooperation, represented by the "ten-plus-three" process (the ten members of the Association of South East Asian Nations (ASEAN) plus China, Japan and South Korea) and the East Asia Summit, is emerging. East Asia is surging economically, and this development helps explain why experts perceive that power and influence in international relations are shifting toward Asia. What happens to order in East Asia will significantly affect the role Asia plays in the emergence of any Asia-centric international system. Thus, it is appropriate to think about the future of the East Asian order, and the most important relationship for this future is between China and Japan.

This article's analysis proceeds in five parts. First, I provide an overview of order in the East Asian region, emphasizing the importance of economic integration and the pivotal role of Sino-Japanese relations in the formation of a new type of order in East Asia.

Second, the article considers some conceptual and definitional issues concerning order formation in international relations. Specifically, I look at definitions of international order and examine some new aspects of order formation in the early twenty-first century, which I call power shift, problem shift, and paradigm shift. These developments affect the

* KF Chair Professor and Deputy Director of the Center of International Strategic Studies, Party School of CPC Central Committee. The views expressed here are solely mine and do not necessarily reflect those of the Central Party School.

1. For purposes of this article, "East Asia" encompasses the countries of Northeast Asia and Southeast Asia.

Indiana Journal of Global Legal Studies Vol. 17 \#1 (Winter 2010)

(C) Indiana University Maurer School of Law 
logic of regional order formation generally and in East Asia specifically.

Third, I explore the dynamics of the evolving East Asian order. I begin with a look at past and present orders in East Asia and then analyze the five key features of order formation in East Asia: (1) the importance of economic integration and its spillover effects, (2) the comprehensive and peaceful rise of China, (3) Japan's pursuit of greater political roles regionally and globally, (4) the leading role played in East Asian order formation by ASEAN, and (5) strategic adjustments being made by the United States.

Fourth, I consider the future of the East Asian order and argue that the key to its further development revolves around the relationship between China and Japan.

Finally, I outline a strategic framework for future Sino-Japanese relations based on the convergence and institutionalization of their common interests bilaterally, regionally, and globally. This framework takes into account the complexity of Sino-Japanese relations, identifies the common interests in which a strategic framework can be grounded, and looks at possible strategic measures China and Japan can take to move East Asian order formation forward.

\section{OVERVIEW OF THE EAST ASIAN ORDER}

\section{A. The Importance of East Asian Economic Integration}

Rapid economic integration in East Asia has proved to be the main catalyst of regional cooperation. The pace of economic integration indicates that the region is a natural trade territory, but this integration has increasingly facilitated regional cooperation beyond trade and investment. Economic integration has produced spillover effects in the form of political and security dialogues, functional coordination in some areas of low politics, and intensive social interactions among countries in the region. As the East Asian order matures, politics-especially political considerations at the strategic level-will drive regional cooperation, coordination, and integration.

Since the end of the Cold War, economic integration in East Asia has seen steady progress. Even the bitter experience of the Asian financial crisis in the late 1990 s triggered comprehensive efforts toward better economic and financial coordination. Thus, trade, investment, and financial cooperation have been enhanced. In the early years of the twenty-first century, free trade agreements (FTAs), both bilateral and multilateral, have become an important trend in East Asian economic integration. However, the difficulties China and Japan have experienced in negotiating a bilateral FTA shows that FTAs in East 
Asia do not constitute a framework for regional cooperation that encompasses all economies. The institutional aspects of regional economic cooperation have, therefore, lagged behind the substantive integration that has taken place between East Asian economies.

Politics and economics interact, and political factors have observable effects on economics. ${ }^{2}$ Economic integration is not only an attempt to increase economic growth and achieve other economic objectives, but it is also an effort to regain some measure of political control over economic globalization, which has constrained national policy instruments. ${ }^{3}$ Economic interdependence, by itself, is insufficient to establish a steady regional order in East Asia. Such interdependence does not operate at the nation-state level, nor does it necessarily require the creation of security arrangements, features that any sustainable regional order or community must exhibit.

Regionalism provides East Asian countries with not only the opportunity for economic integration but also the impetus for political dialogues and security cooperation. The ten-plus-three framework is the main channel of East Asian economic and political cooperation. This framework is transforming from a market-driven mechanism into an arrangement where economic, political, and security institutions are becoming more prominent. ASEAN countries have set up a comparatively mature subregional order in Southeast Asia, while the three Northeast Asian countries-China, Japan, and South Koreahave promised through the ten-plus-three framework to enhance political trust among themselves and with ASEAN members.

However, these developing political dialogues and cooperative efforts have only managed to address problems remaining from past political confrontations and other long term security problems. The slow progress made on political and security issues is exacerbated by the fact that countries in East Asia think nationally, talk regionally, and yet always act bilaterally. Thus, the development of a positive, strategic framework for order in East Asia is still wanting.

Nevertheless, as East Asia enters into a new era of engagement, the predominant trend there is toward boosting interdependence among countries. Cooperation and cooperative development have become the focus of a common vision for the future of East Asia, and a community

2. See James D. Morrow et al., The Political Determinants of International Trade: The Major Powers, 1907-90, 92 AM. POL. SCI. REv. 649, 649 (1998); Susan Strange, Political Economy and International Relations, in INTERNATIONAL RELATIONS THEORY TODAY 154, 169-70 (Ken Booth \& Steve Smith eds., 1995).

3. Peter J. Katzenstein \& Takashi Shiraishi, Conclusion: Regions in World Politics: Japan and Asia-Germany in Europe, in NETWORK PowER: JAPAN AND ASIA 341, 344 (Peter J. Katzenstein \& Takashi Shiraishi eds., 1997). 
dedicated to coexistence and joint prosperity is emerging within the overall development of economic interdependence and in response to the growing severity of some nontraditional security problems.

\section{B. A New East Asian Order Under Formation}

A formal, institutionalized East Asian Community is a lofty goal promising a bright future for regional order, but this goal remains very distant. Order in East Asia is a traditional but crucial component of analyzing the prospects for regional integration, although the concept faded after the Second World War because of historical legacies (e.g., Japan's aggression during the 1930s and 1940s) and intervention from great powers outside the region (e.g., the United States). Great powers talk frequently about global or international order, but regional orders are the pillars of the global one, and a chaotic order in East Asia would be a severe problem for these same powers and for global order in the future.

In the early stages of East Asian integration, economics united nations, but politics divided them. The complexity of East Asian power relations made political cooperation difficult. This difficulty stemmed from the competing interests of relevant actors inside and outside the region, as well as from the asymmetries and rapid changes in the power profiles of these actors. Yet, gradually, the spillover effects of economic interdependence pushed forward more regional cooperation and a greater momentum for regionalism generally. The norms and institutions that have been emerging through efforts on regional economic integration have helped East Asian countries to mitigate intraregional power asymmetries that would otherwise aggravate the security dilemma existing among them. ${ }^{4}$ Meanwhile, a patchwork of bilateral alliances, ad hoc security dialogues, multilateral forums, ministerial meetings, track two encounters, and other mechanisms of engagement developed across the region. ${ }^{5}$ Although political mistrust and security distrust still impede more comprehensive regional cooperation, most countries involved realize that the route to future order building in East Asia is not through hegemony or war, but through the convergence and institutionalization of common interests among them.

4. Amitav Acharya, Will Asia's Past Be Its Future?, INT'L. SECURITY, Winter 2003-04, at 149,150 .

5. G. John Ikenberry \& Jitsuo Tsuchiyama, Between Balance of Power and Community: The Future of Multilateral Security Co-operation in the Asia-Pacific, 2 INT'L REL. ASIA-PAC. 69, 70 (2002). 
In essence, order formation is a process of common interest convergence and institutionalization. Japan and China are the two crucial pillars of East Asian integration and of any stable East Asian order. Before the mid-1990s, East Asia had no regionwide institutional framework for economic integration. At that time, Japanese investment in East Asia was largely responsible for the growing common prosperity in the region. However, the 1997-98 Asian financial crisis triggered more concerted efforts at regional economic cooperation and, since that crisis, the Chinese economy has assumed the role of leading regional economic integrator. Yet, in the process of East Asian order formation, ASEAN has played the leading role because it has provided the framework within which the leading East Asian powers have cooperated on both political and security issues. In addition, ASEAN and the United States play counterbalancing roles in the formation of an East Asian order.

Deeper levels of cooperation in East Asia emerged in economics and functional low politics issue areas and from the challenges created by the Asian financial crisis. East Asian cooperation is now at a crossroads because the great powers in the region-Japan and China-need to determine what types of political and security cooperation they wish to develop.

\section{Sino-Japanese Relations: The Pivotal Factor of East Asian Order}

As important as ASEAN has been in playing a leading role in facilitating greater cooperation among East Asian countries, its ability to push East Asian order formation farther and faster is very limited. The keys to such order formation are reconciliation, cooperation, and coordination between China and Japan.

China's economic rise and Japan's political rise are the principal catalysts to the emerging regional order, but the mistrust between China and Japan is a daunting obstacle facing East Asian order formation. The "Two Tigers Dilemma"-no two rival tigers can exist in the same territory-makes it difficult for the two countries to identify and institutionalize common interests. Sino-Japanese competition profoundly affects the process of regional, economic institution building in all core dimensions: the nature of preferential trade ties between Northeast and Southeast Asian nations, the proliferation of overlapping FTA networks, and the rekindled debate on the inclusivity and exclusivity of economic integration processes. On security issues, a traditional security dilemma between the two countries exists, which makes it difficult to foster mutual trust, mutual benefit, and interdependence. Strategic mistrust between the two countries sharpens 
the East Asian security dilemma and hinders multilateral security institution building.

Certainly, the future of any East Asian order depends on the nature of Sino-Japanese relations. Avoiding or resolving the "Two Tigers Dilemma" is necessary to facilitate more stable East Asian order building. How Japan and China move forward will also determine how the shift of power and influence toward Asia will operate and be perceived by other countries. Japan and China will thus determine what happens to East Asia at its present strategic crossroads.

\section{THE LOGIC OF REGIONAL ORDER FORMATION}

\section{A. Definitions of International Order}

Hedley Bull defined international order as "a pattern of activity that sustains the elementary or primary goals of the society of states, or international society." ${ }^{6}$ Bull identified three sets of rules necessary to maintain order: principled or constitutive rules (the system of states as the foundation for order), rules of coexistence (states respect the sovereignty of other states), and rules of cooperation (legal and other rules that govern interaction among states and societies). ${ }^{7}$ G. John Ikenberry defined international political order as the governing arrangements among a group of states: "The focus is on the explicit principles, rules, and institutions that define the core relationships between the states that are party to the order. This limits the concept of order to settled arrangements between states that define their relationships to each other and mutual expectations about their ongoing interaction." 8 In Ikenberry's view, institutions both limit and project state power, thus playing a key role in order building and maintenance. ${ }^{9}$

International order, this article submits, is based on the power relations among great powers in any given period of time, and it flows from the distribution of power and interests between and among the great powers. The stability of an international order depends on (1977).

6. HEDLEY BULL, The ANARCHICAL SOCIETY: A STUdY OF ORDER IN WORLD POLITICS 8

7. Id. at 67-70.

8. G. JOHN IKENBERRY, AFTER VICTORY: INSTITUTIONS, STRATEGIC RESTRAINT, AND THE REBUILDING OF ORDER AFTER MAJOR WARS 23 (2001).

9. Institutionalists argue that institutions can enable states to achieve their own objectives more efficiently and that order can be maintained through an ever-growing set of agreements and institutions. See generally EXPLORATION AND CONTESTATION IN THE STUDY OF WORLD POLITICS (Peter J. Katzenstein et al., eds., 1999). 
whether the great powers can come to terms on the core ideas or conceptions of the order. ${ }^{10}$ International institutions or regimes, which include principles, norms, rules, and decision-making procedures, are the crucial variables in order formation.

International order is usually facilitated by the building and functioning of international institutions. International order is a kind of public good, which is provided by the most powerful and important states in international society, and it both reflects and leads to cooperation and conflict among great powers. Nevertheless, order formation is always based on common interest convergence and institutionalization. In Charles P. Kindleberger's view, public goods can play the role of stabilizer in international order and their underproduction on the international level is a serious problem. ${ }^{11}$ Robert O. Keohane and Joseph S. Nye, Jr. argue that hegemony is not the sole provider of public goods, but a few great powers can provide public goods, thus stabilizing international order. ${ }^{12}$

International order among states has taken many different forms, but balance-of-power, hegemonic, and community-based orders are the most important. In the balance-of-power order, the power of the leading state is counterbalanced by the powers of other states, with coalitions shifting as power distributions change. A hegemonic order is organized and maintained by a state wielding a predominance of power capabilities. This dominant power shapes the international order in which relations between states are stable and follow certain patterns and rules of behavior determined by the dominant power. ${ }^{13} \mathrm{~A}$ community-based order exists where binding security institutions and shared political interests and values shape the way states exercise power; the distribution of power may still matter, but not to the same extent as in balance of power or hegemonic orders. ${ }^{14}$

\section{B. New Dynamics of Order Formation: Power Shift, Problem Shift, and Paradigm Shift}

Order is always in the process of transformation as great powers rise and fall. Since the end of the Cold War, or even since the end of Second World War, with globalization and regionalization surging in

10. See Albert S. Yee, The Causal Effects of Ideas on Policies, 50 INT'L ORG. 69 (1996).

11. ChARLES P. KINDLEBERGER, International Public Goods without International Government, in THE INTERNATIONAL ECONOMIC ORDER 123, 125 (1988).

12. RoberT O. KeOHANE \& JOSEPH S. NYE, JR., POWER AND INTERdePENDENCE 18-19 (3d. ed. 2001).

13. A. F. K. ORGaNSKI, WORLD POLITICS 313-30 (1958).

14. Ikenberry \& Tsuchiyama, supra note 5, at 87-90. 
differently timed waves, new dynamics of order formation emerge, namely power shift, problem shift, and paradigm shift. ${ }^{15}$

\section{Power Shifts}

"Power shift" describes the way that globalization and regional integration have transformed the actors and the configuration of power internationally. Regionalism and regionalization have become both generators and accumulators of power resources for states. With the expansion of globalization, self-reliance by states is not regarded as a realistic choice. Regional economic cooperation, followed by economic integration, have become new global trends and are regarded as the great powers' strategic choices. The world has entered a third century of rapid growth driven by science and technology. Accordingly, economics and technology, instead of politics, war, and security, have played an increasingly dominant role in order formation.

Globalization and regionalism have factored into many important power shifts that have occurred over the past few decades: Japan's economic and political rise since the 1980 s, the hegemony of the United States in the immediate post-Cold War period, and the economic and political development of China, India, Russia, and Brazil. The nature of these power shifts involves not just hard power but, increasingly, the utilization of soft power in international relations. Another power shift encouraged by globalization has been the growth in the power and influence of nonstate actors, such as multinational corporations, nongovernmental organizations, and terrorist and criminal groups. ${ }^{16}$ of course, these power shifts have also contributed to order-threatening problems, such as state failure, ${ }^{17}$ which create new kinds of challenges for maintaining and deepening international and regional stability.

\section{Problem Shifts}

Along with power shifts, countries must deal with shifting problems. Some newly emerging problems or issues stand out as new priorities on international agendas, and these challenges have grown as national concerns in terms of their security, political influence, and economic

15. See Men Honghua, Power Shift, Problem Shift and Paradigm Shift: A Study of the Hegemonic Explanation Model, AM. STUD. Q., Fall 2005, at 7 (analyzing the transmutation of the world and U.S. hegemony and the theoretical model in explaining this U.S. hegemony).

16. Jessica Mathews, Power Shift, Foreign AFF., Jan.-Feb. 1997, at 50, 50.

17. See Men Honghua, Remedial Measures for Failed States: A Strategic Dimension of Sino-American Security Cooperation, AM. STUD. Q., Spring 2004, at 7. 
development and prosperity.

First, more global issues have emerged. Terrorism, drug and arms smuggling, public health and environmental problems, resource scarcity and depletion, migration and other human flows across national borders are all worldwide problems, which can only be effectively addressed with the cooperation and coordination of many countries. The great powers alone cannot resolve these global problems. ${ }^{18}$ Accordingly, global issues blur traditional internal and external boundaries and require a level of understanding of the national interests of others. Thus, global problems act as restraints on the great powers and can strengthen the sense of solidarity in the international community. ${ }^{19}$

Second, the emergence of more global problems has increased the importance of finding new ways of cooperating globally and regionally. Many global problems threaten economic development and security, and they entangle science, technology, information, ecology, and other issues in security discussions. As nontraditional security problems, these global challenges can facilitate a more cooperative relationship in achieving national, regional, and global security.

Third, the need for new solutions and innovative regimes to address global problems highlights existing problems with international institutions, such as their "democratic deficit," and many countries, including the great powers, have begun to reevaluate their significance and potential contributions to order formation and stabilization.

\section{Paradigm Shifts}

Power and problem shifts suggest that international affairs should undergo some paradigm shifts in how states and nonstate actors analyze and behave in world affairs. For great powers, globalization and regionalization act as constructive strategic straitjackets, making the pursuit of national interests more a matter of relative than absolute

18. Dennis C. Blair \& John T. Hanley, Jr., From Wheels to Webs: Reconstructing AsiaPacific Security Arrangements, WASH. Q., Winter 2001, at 7, 8; see also Tsuneo Akaha, Non-traditional Security Cooperation for Regionalism in Northeast Asia, in BROADENING AsIA's SECuRITY Discourse AND AGENDA: POLITICAL, SOCIAL, AND ENVIRONMENTAL PERSPECTIVES 306 (Ramesh Thakur \& Edward Newman eds., 2004) (arguing that multilateral cooperation over nontraditional security issues will contribute to the building of mutual confidence in Northeast Asia); Men Honghua, New Security Concept, Interest Community and Strategic Thoroughfare: An Explanation to China's Security Interest, TEACHING \& RES., Aug. 2004, at 68 (supporting the development of an international interest community between China and other nations to accelerate the integration of China into international society).

19. Jean-Marie Guehenno, The Impact of Globalization on Strategy, SURVIVAL, Winter 1998-99, at 5, 8 . 
gains. ${ }^{20}$ The need to address global challenges and nontraditional security threats makes power relations among countries look less like zero-sum games and more like opportunities to create positive-sum or win-win collective solutions. In the regional perspective, open regionalism is widely accepted, and regional structures and regimes focused on functional issues could produce a more durable order with liberal principles operating as constitutive rules.

Table 1. Power Shift, Problem Shift, and Paradigm Shift

\begin{tabular}{|l|l|l|l|}
\hline & Power Shift & Problem Shift & Paradigm Shift \\
\hline Level & $\begin{array}{l}\text { Rise of NGOs, } \\
\text { multinational } \\
\text { and } \\
\text { transnational } \\
\text { corporations. }\end{array}$ & $\begin{array}{l}\text { Domestic reform } \\
\text { and openness; } \\
\text { State-society } \\
\text { relations. }\end{array}$ & $\begin{array}{l}\text { Domestic } \\
\text { governance. }\end{array}$ \\
\hline $\begin{array}{l}\text { Bilateral } \\
\text { Level }\end{array}$ & $\begin{array}{l}\text { powational } \\
\text { Rise of } \\
\text { nationalism and } \\
\text { statism. }\end{array}$ & $\begin{array}{l}\text { Bilateral } \\
\text { agendas expand } \\
\text { and become more } \\
\text { penetrating. }\end{array}$ & $\begin{array}{l}\text { Dialogue } \\
\text { replaces } \\
\text { confrontation, } \\
\text { though rivalry } \\
\text { remains; } \\
\text { Competition on } \\
\text { soft power. }\end{array}$ \\
\hline $\begin{array}{l}\text { Regional } \\
\text { Level }\end{array}$ & $\begin{array}{l}\text { Regionalism and } \\
\text { regionalization } \\
\text { become both } \\
\text { generators and } \\
\text { accumulators of } \\
\text { power resources } \\
\text { for states. }\end{array}$ & $\begin{array}{l}\text { More regional } \\
\text { conflicts are } \\
\text { avoided; } \\
\text { Traditional and } \\
\text { nontraditional } \\
\text { security } \\
\text { problems take on } \\
\text { increased } \\
\text { importance. }\end{array}$ & $\begin{array}{l}\text { Regional } \\
\text { integration and } \\
\text { more important; } \\
\text { Regionalism has } \\
\text { counterbalancing } \\
\text { effects globally. }\end{array}$ \\
\hline Global \\
Level & $\begin{array}{l}\text { Globalization; } \\
\text { Rise of new great } \\
\text { powers; } \\
\text { Economy and } \\
\text { technology play } \\
\text { more dominant } \\
\text { roles. }\end{array}$ & $\begin{array}{l}\text { Nontraditional } \\
\text { security } \\
\text { problems; } \\
\text { North-South } \\
\text { conflict replaces } \\
\text { East-West } \\
\text { conflict as the } \\
\text { main concern. }\end{array}$ & $\begin{array}{l}\text { Democratic } \\
\text { deficit of } \\
\text { international } \\
\text { institutions; } \\
\text { Global } \\
\text { governance. }\end{array}$ \\
\hline
\end{tabular}

20. Joseph Grieco, Robert Powell \& Duncan Snidal, The Relative-Gains Problem for International Cooperation, 87 AM. PoL. SCr. Rev. 729, 729 (1993). 


\section{The Logic of Regional Order Formation}

International order is often treated as a byproduct of military threats, and the possibility of nonviolent international orders that develop as a byproduct of interstate collective identity is typically regarded as uncertain. ${ }^{21}$ Yet, regionalism and its spillover effects can affect how we think about order formation. In reality, regional order formation depends not only on power relations and the self-interest of the countries involved, but also on such process factors as idea innovation, collective identity, and institution building. Robert Cox argues that any international order is the interaction of three forces: power distribution, the role of institutions, and collective identity, with consistency among the three forces contributing to a stable, preferred order. $^{22}$

In regional order formation, economic integration is always regarded as the bellwether of regional cooperation. Cooperation, coordination, and compromise become mainstream behaviors in the integration process; and rules, norms, principles, and coordinative decision making procedures gradually become accepted by all participants and are institutionalized as the hard and soft laws of the region.

These institutionalized factors typically include the following items: (1) reciprocity, which means that participating states pursue not only self-interests, but the common interests of the whole region; (2) progressiveness, which means displaying tolerance and patience while waiting for consensus to form; (3) inclusivity and openness to outside actors, which accepts involvement by states located in different regions; (4) multilateral coordination and traditional bilateralism, which work simultaneously; and (5) reinsurance arrangements, such as cooperative security arrangements. All the factors above reflect the pursuit of common interests, and the formation and maintenance of these common interests should be regarded as the principium of the regional community. Since distributions of power are usually uneven or asymmetric within regions, small or weak states can, through regionalism, counterbalance regional great powers. Conversely, the coordination, cooperation, and compromise of great powers are essential to regional order formation, and great powers generally mitigate suspicion by providing regional public goods and seeking strategic trust with smaller and weaker states.

21. Janice Bially Mattern, The Power Politics of Identity, 7 EUR. J. INT'L REL. 349, 349 (2001).

22. See Robert Cox, Social Forces, States and World Orders: Beyond International Relations Theory, in NEOREALISM AND ITS CRITICS 204 (Robert O. Keohane ed., 1986). 
The convergence and institutionalization of common interests is the only workable way to build a constructive regional order. Common interests not only refer to the interest in gaining mutual benefits but also to the need to address common global challenges. No country in the world can ward off present-day terrorism, the drug threat, and other transborder challenges at a time of intensifying globalization of political, economic, and social processes. In this context, the pressing need for broad collaboration among all countries, both at the regional and global levels, and for a practical contribution of each nation toward the solution of these global problems are beyond doubt. In sum, formation of a constructive regional order should be based on the convergence of common interests between and among regional states.

\section{DYNAMICS OF THE Evolving EAST ASIAN ORDER}

Countries in East Asia have a long history of trying to create regional order. Today, East Asian states embrace both the globalization and regionalization waves, and, in the process, are beginning to think about the future framework of the regional order. Regional economic integration and its spillover effects, China's comprehensive and peaceful rise as a great power, Japan's political pursuit of a greater role both in regional and world arenas, ASEAN's normative influences, and the United States' strategic adjustments in the region, are the main forces that will affect East Asian order formation and determine not only the openness of the regional order, but also the process and roadmap of its building.

\section{A. East Asian Order: Past and Present}

The idea of regional cooperation in Asia has a long history, and the pursuit of an East Asian order has rich, yet heavy, historical legacies. The three most important attempts before the Second World War to create order within East Asia were ancient China's Tribute System, the United States' Open Door Policy, and Japan's Greater Asia CoProsperity Sphere. ${ }^{23}$

In ancient times, China played the leading role in the formation of a regional East Asian order. The imperial "Tribute System" was a culturally based hierarchical order in which the Celestial Empire provided such public goods as political authorization, concessionary

23. See Norman Palmer, The New Regionalism in Asla and the Pacific 45 (1991) (quoting ROY KIM \& HILARY CONROY, NEW TIDES IN THE PaCIFIC: PaCIFIC Basin COOPERATION AND THE BIG FOUR (JAPAN, PRC, USA, USSR) (1987)). 
trade opportunities, and security guarantees to the feudatory neighboring states, which paid tribute and submitted to the supremacy of China. China's supremacy and Sino-centrism were reflected not only in cultural exchanges but also in political structures and economic interactions. Invasion and colonization by Western industrial countries caused the collapse of the Chinese Tribute System in the middle of the nineteenth century, which led to the United States' push for the Open Door Policy by the end of the nineteenth and start of the twentieth century. However, the Open Door Policy was a balance-of-power order that served the interests of outside imperial powers rather than the wishes of the countries of East Asia. The Greater Asia Co-Prosperity Sphere pursued by Japan in the 1930s and 1940s was also an unequal, colonial arrangement, which was perpetrated by the leading Asian power of that time.

Both China's Tribute System and Japan's Greater Asia CoProsperity Sphere were hegemonic orders. The main difference between them was that China's Tribute System was dominated by the belief in Chinese cultural supremacy, while Japan's Greater Asia Co-Prosperity Sphere was dominated by military conquest. The historical legacies of China's Tribute System, when combined with China's economic rise since the 1980s, create some perceptions that China poses a threat in East Asia and other regions. ${ }^{24}$ These perceptions give China pause in taking the lead in building new East Asian regional institutions and processes. Given the problems that the Greater Asia Co-Prosperity Sphere caused, Japan is also reluctant to take the initiative on building a new East Asian order. This history explains why China and Japan so far have mainly focused on issues of global order and have spent little time and attention on pushing for a new kind of order in East Asia. ${ }^{25}$ It might also help explain why China and Japan agree that ASEAN could play a leading role in regional order design and corresponding practices.

Since the end of Second World War, there have been three partial regional ordering arrangements in East Asia, namely, the U.S.-led security system, the Japan-led economic order (the "Flying Geese" $\operatorname{order}^{26}$ ), and the ASEAN subregional order. The U.S.-led security

24. Dai Fan \& Zhou Yu'e, Towards a Unified East Asian Order?, PAC. J., issue no. 12, 2005 , at 22 .

25. It has been argued that over the past half century, there was no original approach to having regional ideas in East Asia because proposing such ideas was considered imperialistic. It became taboo to debate how to create a wide-ranging order that spreads across East Asia. See Yonosuke HARA, NEw EASt ASLA Theory 32 (2002).

26. In Kaname Akamatsu's view, division of labor in East Asia was based on dynamic comparative advantage, and the underdeveloped economies in the region could be considered to be aligned successively behind the advanced industrial nations in the order of their different stages of growth in a wild-geese-flying pattern. In this pattern, Japan 
system in East Asia has the character of hegemonic stability, and it is still regarded by many countries as the mainstay of East Asian stability. In the Japan-led Flying Geese order, economic relations, especially foreign direct investment (FDI) and trade, play the leading roles, informed by Japan's strategic interests in the order formation. The Flying Geese order and the ASEAN order have come of age during the recent wave of globalization and regionalization, and they coexist with the U.S.-led security system. East Asia has thus experienced the influence of ASEAN's development, the political and economic rise of Japan and China, and the preservation of U.S. security arrangements. As a result of these overlapping regional ordering mechanisms, a regional balance of power is taking shape.

Given the historical legacies, initiatives on regional order that go beyond what already exists lack a long term vision and a clear roadmap. Therefore, cooperation in East Asia, in general, lacks formal institutionalization, especially compared with other regional orders, such as those in Europe. In addition, a limited, but discernable, "arms walk" has emerged in East Asia between China, Japan, and the United States, indicating that the traditional security dilemma still hinders further cooperation among these great powers. ${ }^{27}$ To be clear, the military trends around the region are not the development of armed forces capable of invading and occupying neighboring states. Instead, the great powers are developing capabilities to inflict damage for intimidation, deterrence, or punishment. ${ }^{28}$ Accordingly, "for years to come the Asia-Pacific will be a region that will exist somewhere between a balance of power order and a community-based security order."29

\section{B. Dynamics of East Asian Order Formation}

\section{Economic Integration and Its Spillover Effects}

To date, economic integration in East Asia has experienced three developmental phases. The period stretching from the $1960 \mathrm{~s}$ to the

was regarded as the lead goose, while the Newly Industrializing Economies (especially "the Four Dragons") were the second tier; after these two groups came the Philippines, Indonesia, Thailand and Malaysia, and finally China, Vietnam and other least developed nations in the region. In many scholars' opinions, Japan set up a regional economic order in East Asia based upon the Flying Geese pattern from the 1960s to the end of the 20th century. See Kaname Akamatsu, A Historical Pattern of Economic Growth in Developing Countries, Developing EcoN., Aug. 1962, at 3.

27. Joseph S. Nye, Jr., China's Re-Emergence and the Future of the Asia-Pacific, SuRVIVAL, Winter 1997-98, at 65, 74.

28. Blair \& Hanley, supra note 18 , at 9.

29. Ikenberry \& Tsuchiyama, supra note 5 , at 69 . 
middle of the 1990s was driven by national policies and national market or investment reforms rather than formal cooperation under bilateral or multilateral frameworks. Japan played the key role in regional economic growth, especially in terms of trade and FDI. The Flying Geese order emerged from these Japanese-led economic interactions. The resulting expansion of trade and FDI became the engine of economic growth and development in East Asia.

The period from 1997 to 2001 was a phase of economic coordination triggered by the Asian financial crisis of 1997-98. States within the region began to take concrete cooperative and coordination measures to respond to this crisis and prevent future severe macroeconomic challenges. Following the crisis, East Asian countries embarked on regional economic cooperation in the areas of trade, investment, currency, and finance. The crisis prompted the national economies to realize the importance of closer cooperation, because they were increasingly interdependent, and to undertake initiatives to institutionalize such interdependence. Thus, coordination in trade, investment, and finance made great progress, which laid solid foundations for future cooperation. It is in this period that China began to play a key role in regional economic cooperation.

The third and current period started with the signing of the Chiang Mai Initiative in May 2000. This initiative is regarded as the milestone of East Asia's institutional economic cooperation to date. Since 2001, economic integration in East Asia-led by the Chiang Mai Initiativehas entered an institution- and strategy-driven phase, and the notion of an East Asian Community is increasingly accepted by most countries in the region. An East Asia Summit has been held twice, and many FTA proposals have been put forward, with some becoming realities. East Asia has become a region characterized by FTAs (see Figure 1), though an overall FTA agreement for the region will not materialize in the near future. In this third phase, China has emerged as the leading economic player in East Asia.

East Asia's stability and prosperity depend on regional economic integration, and the spillover effects of this economic integration in turn strengthen the regional cooperation in political, security, social, and cultural areas. All of these cause some institutional framework to emerge in the ongoing processes. One spillover effect of economic integration is that East Asia is being transformed as a region, and the notion of an East Asian economic community is generally accepted as a goal of regional cooperation. Competition between and among great powers in the region has not led to severe conflict, crisis, or war-so 
far. ${ }^{30}$ Instead, the great powers are more interested in further cooperation with regional economies-obtaining preferential trade and investment treatment-and the provision of more regional public goods. The Asian financial crisis triggered deeper regional cooperation and gave birth to political decisions supporting further economic integration, which meant that the traditional crisis response of "beggar-thyneighbor" was not adopted. In fact, a strong sense among East Asian leaders that the future of their countries is linked to a stable regional and global order was enhanced, and codevelopment and cooperative prosperity became positive driving forces of East Asian cooperation.

Figure 1. Matrix of FTAs Between/Among ASEAN Members and China, Japan, and South Korea (through August 2009)

\begin{tabular}{|c|c|c|c|c|c|c|c|c|c|c|c|c|c|}
\hline & $\stackrel{\Omega}{.}$ & 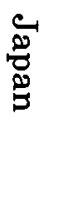 & 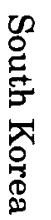 & 窇 & 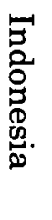 & 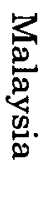 & 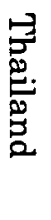 & 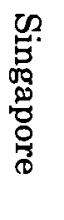 & 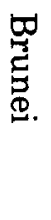 & 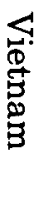 & 空 & 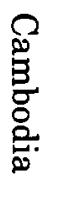 & 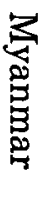 \\
\hline China & 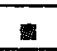 & $\delta$ & $\delta$ & (B) & (B) & (B) & (B) & (B) & (B) & (B) & ( & (B) & (R) \\
\hline Japan & $\delta$ & 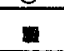 & $\Delta$ & (B) & (B) & (B) & (B) & (B) & (B) & (B) & ( & (B) & (B) \\
\hline South Korea & 0 & $\Delta$ & 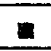 & (B) & ( & () & $\Delta$ & (B) & (B) & (B) & $(\mathbb{B}$ & (B) & (B) \\
\hline Philippines & (B) & (B) & (B) & 1 & (®) & (B) & (8) & (B) & (B) & (B) & (ß) & (B) & (B) \\
\hline Indonesia & (ß) & (ß) & ( & (8) & 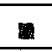 & (ß) & (B) & (B) & $\mathbb{B}$ & (B) & (B) & ( & (B) \\
\hline Malaysia & (B) & (B) & (B) & (B) & (B) & $\square$ & (B) & (B) & (B) & (B) & (B) & (B) & (B) \\
\hline Thailand & (B) & (B) & $\Delta$ & (B) & (B) & (B) & 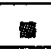 & (B) & (B) & ( & (B) & (B) & (B) \\
\hline Singapore & (B) & (B) & (B) & (B) & (B) & 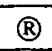 & (B) & - & (B) & ß & (B) & (B) & (B) \\
\hline Brunei & (B) & (B) & (尺) & (B) & (B) & (B) & $(B$ & (B) & $\square$ & (B) & (B) & (B) & (B) \\
\hline Vietnam & (B) & (B) & (B) & (B) & (B) & (B) & (B) & (B) & (B) & 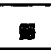 & (B) & (B) & (B) \\
\hline Laos & (B) & (B) & ( & (B) & (B) & ( & ( & (B) & (ㄹ) & ( & - & (B) & (B) \\
\hline Cambodia & (B) & (B) & (B) & (B) & (B) & (R) & (B) & (B) & (B) & (B) & (B) & 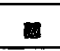 & (B) \\
\hline Myanmar & (B) & (B) & ( & (B) & (B) & (B) & (B) & (B) & (B) & (B) & (B) & (B) & 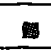 \\
\hline
\end{tabular}

Source: ASEAN, AFTA \& FTAs, http://www.aseansec.org/4920.htm (last visited Oct. 14, 2009).

Notes: $(\circledR)=$ Entered into force or signed;

$\Delta=$ Under negotiation or agree to negotiate bilaterally; $\delta=$ Under consideration or feasibility study initiated.

30. Robert Ross, The Geography of the Peace: East Asia in the Twenty-First Century, INT’L SECURITY, Spring 1999, at 81. 


\section{The Comprehensive and Peaceful Rise of China}

Initiating economic reform and opening to the outside world since the late 1970s have shaped China as the fastest-growing economy in the world. Since 1978, China has transformed itself more thoroughly and more rapidly than any society in history. More than three decades of high growth, generally estimated at 9.8 percent annually, have made China the world's third largest economy and the third largest trading nation of the world.

East Asian economies have made great contributions to China's economic rise (see Table 2), while China, at the same time, provides market and other economic opportunities for its neighbors. Of its twenty-six neighboring economies in 1995, mainland China was the largest trading partner of one neighboring economy, the second-largest trading partner of nine neighboring economies, and the third-largest trading partner of one neighboring economy (see Table 3). In 2005, mainland China became the largest trading partner of nine neighboring economies, the second-largest trading partner of seven neighboring economies, and the third-largest trading partner of five neighboring economies (see Table 3). Accordingly, mainland China's economic interdependence with its neighboring economies has increased significantly in recent years.

Table 2. FDI Flows into China (\%)

\begin{tabular}{|l|l|l|l|l|l|l|l|l|l|}
\hline & 1998 & 1999 & 2000 & 2001 & 2002 & 2003 & 2004 & 2005 & 2006 \\
\hline Hong Kong & 40.7 & 40.6 & 38.1 & 35.7 & 33.9 & 33.1 & 31.3 & 29.8 & 32.1 \\
\hline Taiwan & 6.4 & 6.4 & 5.6 & 6.4 & 7.5 & 6.3 & 5.1 & 3.6 & 3.4 \\
\hline Japan & 7.5 & 7.4 & 7.2 & 9.3 & 7.9 & 9.4 & 9.0 & 10.8 & 7.3 \\
\hline South Korea & 4.0 & 3.2 & 3.7 & 4.6 & 5.2 & 8.4 & 10.3 & 9.4 & 6.2 \\
\hline Singapore & 7.5 & 6.6 & 5.3 & 4.6 & 4.4 & 3.8 & 3.3 & 3.7 & 3.6 \\
\hline East Asia & 66.1 & 64.1 & 59.9 & 60.5 & 61.4 & 61.1 & 62.0 & 59.2 & 52.6 \\
\hline
\end{tabular}

Source: China's Statistics Yearbook, from 1999 to 2007.

In addition, China has recently been providing more regional public goods, such as macroeconomic stability, preferential trade treatment, and cooperation in nontraditional security. The spillover effects of China's economic rise became the main factors in East Asian economic interdependence in the late 1990s. It has been noted that, "for all these countries in Asia, China is such a large force, the only rational response 
is to figure out how to work with it."31

Table 3. Trading Relations Among Mainland China and Its Neighboring Economies

\begin{tabular}{|l|l|l|l|}
\hline China as: & \multicolumn{1}{|c|}{1995} & \multicolumn{1}{c|}{ 2000 } & \multicolumn{1}{c|}{ 2005 } \\
\hline $\begin{array}{l}\text { Largest } \\
\text { Trading } \\
\text { Partner }\end{array}$ & Hong Kong & $\begin{array}{l}\text { Mongolia, Hong } \\
\text { Kong, and North } \\
\text { Korea }\end{array}$ & $\begin{array}{l}\text { Macao, Chinese } \\
\text { Taipei, } \\
\text { Mongolia, North } \\
\text { Korea, South } \\
\text { Korea, Japan, } \\
\text { Kyrgyzstan, and } \\
\text { Vietnam }\end{array}$ \\
\hline $\begin{array}{l}\text { Second } \\
\text { Trading } \\
\text { Partner }\end{array}$ & $\begin{array}{l}\text { Kazakhangtan, } \\
\text { Kyrgyzstan, } \\
\text { Japan, Mongolia, } \\
\text { Chinese Taipei, } \\
\text { North Korea, } \\
\text { and Burma }\end{array}$ & $\begin{array}{l}\text { Japan, Macao, } \\
\text { Chinese Taipei, } \\
\text { Pakistan, } \\
\text { Burma, and Laos }\end{array}$ & $\begin{array}{l}\text { Kazakhstan, } \\
\text { India, Laos, } \\
\text { Burma, } \\
\text { Pakistan, } \\
\text { Philippines, and } \\
\text { Russia }\end{array}$ \\
\hline $\begin{array}{l}\text { Third } \\
\text { Largest } \\
\text { Trading } \\
\text { Partner }\end{array}$ & South Korea & $\begin{array}{l}\text { Kazakhstan, } \\
\text { South Korea, } \\
\text { Kyrgyzstan, } \\
\text { Nepal, Russia, } \\
\text { Vietnam, and } \\
\text { Tajikistan }\end{array}$ & $\begin{array}{l}\text { Singapore, } \\
\text { Malaysia, Nepal, } \\
\text { Tajikistan, and } \\
\text { Thailand }\end{array}$ \\
\hline
\end{tabular}

Sources: Paul Bairoch, International Industrialization Levels from 1750 to 1980, 11 J. Eur. Econ. Hist. 269, 269-335 (1982); Angus Maddison, The World Economy 213-20 (2006); Direction of Trade Statistics 2006 (IMF CD-ROM, 2007).

China's interest is to create a peaceful, prosperous, and stable environment for its modernization goals, so it is now satisfied to play a constructive and increasingly active role in the world arena and regional integration. Accordingly, China has become a powerhouse of world economic growth (see Table 4), the stabilizer of regional macroeconomic prosperity, and the accelerant of regional integration.

31. Jane Perlez, China Emerges as Rival to U.S. in Asian Trade, N.Y. TIMES, June 28, 2002, available at http://www.nytimes.com/2002/06/28/world/china-emerges-as-rival-to-usin-asian-trade.html?scp=1\&sq=\&st=nyt. 
Table 4. China's Contribution to World Incremental GDP (\%)

\begin{tabular}{|l|l|l|}
\hline Country & $\mathbf{1 9 9 0 - 2 0 0 5}$ & $\mathbf{2 0 0 6 - 2 0 2 0}$ \\
\hline China & 28.14 & 36.6 \\
\hline United States & 19.31 & 16.2 \\
\hline Japan & 2.95 & 1.9 \\
\hline Other OECD Countries & 18.33 & 13.8 \\
\hline India & 9.46 & 11.9 \\
\hline Other Asian Developing Countries & 7.13 & 7.4 \\
\hline Latin America & 7.14 & 6 \\
\hline
\end{tabular}

Source: David Dollar, Asian Century or Multi-polar Century? (World Bank, Policy Research Working Paper No. WPS 4174, 2007), available at http://ideas.repec.org/p/wbk/wbrwps/4174.html.

Historically, rising great powers have been regarded as challengers to the existing order and have often precipitated major wars. China's rise has also evoked concerns from its neighbors and other major powers, including the United States. However, China and its neighbors have found ways of mitigating many of these concerns, principally through a process of integrating China into the region through its participation in a number of institutions based on the principles of cooperation and consensus. Such institutions do not, in and of themselves, meet all the standard security needs of member states, but they are well suited to improving relations between states that are neither adversaries nor allies. ${ }^{32}$

China is a cooperative builder of the emerging regional institutions. In the process of mutual engagement, China becomes a responsible stakeholder within East Asia. China's policy is gradually but steadily focused on matters that relate to what is good globally and regionally, as well as what is needed internally. David Kang summarizes the improvement of China's relations with its East Asian neighbors by concluding that "[h]istorically, it has been Chinese weakness that has led to chaos in Asia. When China has been strong and stable, order has been preserved. East Asia regional relations have historically been more peaceful and more stable than those in the West." 33

32. Michael Yahuda, The Evolving Asian Order, in PowER SHIFT: CHINA AND ASIA'S New DYNAMICs 347, 347 (David Shambaugh ed., 2005).

33. David C. Kang, Getting Asia Wrong: The Need for New Analytical Frameworks, INT’L SECURITY, Spring 2003, at 57, 66. 
China, so far, has played constructive diplomatic roles in regional affairs. ${ }^{34}$ Its new regional posture is summarized by David Shambaugh as participation in regional organizations, establishment of strategic partnerships, deepening bilateral relationships, expansion of regional economic ties, and reduction of distrust and anxiety in the security sphere. ${ }^{35}$ In the realist view, the East Asian order under formation is structurally asymmetrical and, thus, unstable. Yet, from the liberal institutionalist perspective, China's reemergence and participation in economic interdependence channels and shapes the evolving environment, including the institution building that is a key factor in order formation. From the constructivist outlook, China is being socialized into a set of norms that will not only pacify it but also will make Beijing a status quo power and cooperative partner. ${ }^{36}$

\section{Japan's Pursuit of Greater Political Roles in Both World and Regional Arenas}

For Japan, economic growth, political stability, and security in East Asia are critically important because of its geographical proximity. Japan, as the second largest economy of the world, is the pioneer in regional economic cooperation, and it remains one of the investment powerhouses of East Asia (see Table 5). From the 1960s to the middle of the 1990s, Japan's Official Development Assistance (ODA), FDI, and relocation of production facilities acted as driving forces of East Asia's economic development. Japan played a comparatively dominant role in how the region's economic order functioned. The Flying Geese order represented both Japan's economic strength and its leading regional role in East Asia.

Japan's economic ambitions have largely been fulfilled because it has become the second-largest economy in the world and one of the world's most affluent societies. Since the 1980s, however, Japan has affirmed its strategic objective to be a great power politically. The concept of Japan becoming a "normal nation" captured this strategic ambition in the 1990s. In other words, Japan began to pursue the status of a great political power to compliment its economic strength. In light of this goal, Japan has aspirations to play a more influential role in

34. James A. Schear, Regional Conflicts: Strategies for Quelling Violence and Prospects for Sino-U.S. Cooperation (Atlantic Council of the U.S.) Feb. 1, 2004, at 18, available at http://www.acus.org/files/publication_pdfs/65/2004-02-Regional_Conflicts.pdf.

35. David Shambaugh, China Engages Asia: Reshaping the Regional Order, INT'L SECURITY, Winter 2004-05, at 64, 72.

36. Nicholas Khoo, Michael L.R. Smith \& David Shambaugh, China Engages Asia? A Caveat Lector, INT'L. SECURITY, Summer 2005, at 196, 210. 
regional and global affairs. In the global arena, Japan seeks increased recognition by, for example, obtaining a permanent seat on the U.N. Security Council. In the regional arena, it seeks to play a leading role in defining and exploring the concept, framework, and main features of an East Asian Community to be built in the foreseeable future.

Table 5. Japan's Outward FDI (Balance of Payments Basis, Net and Flow)

Unit: million USD

\begin{tabular}{|l|l|l|l|l|l|l|l|l|l|l|l|}
\hline & 1995 & 1996 & 1997 & 1998 & 1999 & 2000 & 2001 & 2002 & 2003 & 2004 & 2005 \\
\hline Asia & 8447 & 9749 & 13114 & 7814 & 1811 & 2132 & 7797 & 8177 & 5028 & 10531 & 16188 \\
\hline ASEAN & 3987 & 5238 & 7780 & 4454 & 1032 & 207 & 4013 & 4256 & 432 & 2800 & 5001 \\
\hline Asia NIEs & 1771 & 3039 & 5228 & 2286 & 728 & -686 & 2459 & 3001 & 31 & 1873 & 4902 \\
\hline ASEAN4 & 3312 & 3836 & 4954 & 3551 & 339 & 1684 & 2920 & 2166 & 773 & 2534 & 4276 \\
\hline China & 3183 & 2317 & 1862 & 1301 & 360 & 934 & 2158 & 2622 & 3980 & 5863 & 6575 \\
\hline $\begin{array}{l}\text { South } \\
\text { Korea }\end{array}$ & 347 & 405 & 172 & 421 & 383 & 1074 & 650 & 437 & 333 & 771 & 1736 \\
\hline Singapore & 676 & 1119 & 2559 & 721 & 595 & -1521 & 951 & 1884 & -457 & 138 & 556 \\
\hline Thailand & 935 & 1337 & 2044 & 1668 & -119 & 593 & 1594 & 528 & 678 & 1867 & 2126 \\
\hline Indonesia & 946 & 1494 & 1570 & 916 & 199 & 585 & 481 & 307 & 484 & 498 & 1185 \\
\hline Malaysia & 371 & 522 & 992 & 445 & -332 & -4 & 570 & 257 & .504 & 163 & 525 \\
\hline Philippines & 1061 & 483 & 349 & 521 & 591 & 510 & 275 & 1074 & 114 & 6 & 441 \\
\hline EU & 3230 & 3214 & 2581 & 2268 & 8334 & 10968 & 17886 & 9770 & 8029 & 7341 & 7873 \\
\hline USA & 9018 & 11114 & 7430 & 6013 & 7140 & 14121 & 7031 & 7441 & 10691 & 7559 & 12126 \\
\hline World & 22651 & 23443 & 26057 & 24627 & 22266 & 31534 & 38495 & 32039 & 28767 & 30962 & 45461 \\
\hline
\end{tabular}

Source: JETRO, Japanese Trade and Investment Statistics, http://www.jetro.go.jp/en/reports/statistics/ (this table is available under "Japan's Outward and Inward Foreign Direct Investment: FDI flow by Country and Region, Historical Data: Outward") (last visited Oct. 14, 2009).

Notes:

1. ASEAN includes Laos and Myanmar from 1998, Cambodia from 1999;

2. Asia NIEs (Newly Industrializing Economies) include Singapore, Taiwan, Hong Kong, and South Korea;

3. ASEAN 4 includes Singapore, Malaysia, Thailand and Indonesia;

4. Due to the EU enlargement, the number of member states has increased (Austria, Finland, and Sweden in 1995; ten accession states in 2004);

5. Here "World" includes countries that are not classified into each 
region, therefore World here is not necessarily equal to the sum of regional components.

Japan has benefited from the U.S.-led regional security order that evolved in East Asia in the post-Second World War era. But economic developments in many East Asian countries and China's rise as an economic powerhouse have transformed the context for regional security. Therefore, the most important measure for Japan to take is to redefine and reaffirm the U.S.-Japan alliance, which is regarded by the two countries as the cornerstone of their bilateral national interests in East Asia.

Southeast Asia is vital to Japan's economy and regional status. Japan has further enhanced its cooperative relations with ASEAN countries by concluding bilateral and multilateral Economic Partnership Agreements (EPAs) with them. ${ }^{37}$ For Japan, FTAs play an effective role in promoting economic integration in East Asia, which contributes to economic growth and political and social stability, which in turn have positive impacts for Japan. ${ }^{38}$ In addition, Japan is eager to establish FTAs with ASEAN members because of their political and strategic importance to Japan. As the first mover in East Asia order formation, Japan does not want to fall behind China in designing and building a regional order. In 2002, then Japanese prime minister Junichiro Koizumi put forward the vision of an enlarged East Asian Community expanding beyond the framework of the ten-plus-three approach, thus revealing Japanese intentions to counterbalance China's increasing regional influence.

\section{ASEAN's Leading Role and Normative Influence}

ASEAN was formed in August 1967 with Indonesia, Malaysia, the Philippines, Singapore, and Thailand as the founding members. By 1999, all countries in Southeast Asia had joined ASEAN, which has become an institutional framework for the whole subregion.

ASEAN is a new model of regional cooperation and regional alliance. In its development and evolving processes, informality and consensus are cherished as the most important principles. The principle of noninterference, both in affairs external to the region and internal to

37. See Agreement on Comprehensive Economic Partnership Among Japan and Member States of the Association of Southeast Asian Nations, Apr. 14, 2008, available at http://www.mofa.go.jp/POLICY/economy/fta/asean/agreement.html.

38. See Shujiro Urata, Japan's FTA Strategy and a Free Trade Area of Asia Pacific, in REVIVING JAPAN's ECONOMY 385 (Takatoshi Ito, Hugh Patrick, \& D.E. Weinstein eds., 2005). 
ASEAN members, is rigidly implemented. Equality is of utmost importance in ASEAN relations, and ASEAN members seek consensus through discussion and consultation, rather than by vote or any form of competition. All proposals are approved unanimously or not at all. Amitav Acharya summarized this model by utilizing the term the "ASEAN Way," 39 which captures the normative power of ASEAN in dealing with regional and global issues. Through the "ASEAN Way," Southeast Asian countries have solved bilateral and multilateral disputes peacefully, and have gradually built up a stable subregional order. Compared to Northeast Asia, Southeast Asia has wider cultural and ethnic diversity. While Northeast Asia is still lacking institutions to support common interests, Southeast Asian nations have already established a higher sense of community within their subregion.

East Asian countries learned from the Asian financial crisis that ASEAN countries could not solve such crises alone and that international institutions, such as the International Monetary Fund, were not reliable. Thus, closer cooperation between Southeast and East Asian colintries became the most viable option. Since then, ASEAN's leading role in regional integration is respected and applauded by other countries inside and outside the region. Accordingly, ASEAN adheres to open regionalism and appeals to cooperative development between economies within and without the region. ${ }^{40}$ ASEAN has continued to play a key role in institutionalizing the potential regional frameworks for establishing a larger East Asian order, and has sought to remain at the center of all regional initiatives as the potential rivalry for leadership between Japan and China has intensified. ASEAN is also taking the lead on institutionalizing the ASEAN Regional Forum (ARF), the ten-plus-three process, and the East Asian Summits.

\section{Strategic Adjustments of the United States}

The United States has important interests in all corners of East Asia, ${ }^{41}$ and it attempts to safeguard its interests in the region through a network of formal and informal institutional arrangements. In the security area, the United States has set up a hub-spoke system in East Asia, with the United States at the center of bilateral ties, by allying with Japan, South Korea, the Philippines, and Thailand. As the cornerstone of these security arrangements, the U.S.-Japan alliance was

39. See Amitav Acharya, Ideas, Identity, and Institution-Building: From the ASEAN Way to the Asia Pacific Way?, 10 PAC. REV. 319, 328-33 (1997).

40. Masahide Shibusawa, Zakaria Haji Ahmad \& Brian Bridges, PACIFIC ASIA IN THE 1990s 101 (1992).

41. Blair \& Hanley, supra note 18 , at 12. 
redefined in the 1990s in light of the end of the Cold War and the emergence of China. The United States is also active in ARF, the sole transregional security process in East Asia. It was the U.S. withdrawal of its armed forces from Southeast Asia in the aftermath of Vietnam that triggered multilateral security dialogues in the region and provided the possibility for regional security regime building. After September 11, 2001, the United States returned to Southeast Asia again, and now plays an even more active role in East Asian security.

The United States is a major economic partner of all the East Asian economies. East Asia's share of U.S. trade is steady at 37 to 38 percent (see Table 6), ${ }^{42}$ and its share in U.S. FDI increased from 15 to 18 percent in recent years (see Table 7). The United States' complicated economic relations with Japan and China always catch the eyes of the world, and economics have become a weatherglass in measuring the United States' overall relations with the two Asian powers.

Table 6. East Asia's Share in U.S. Trade (\%)

\begin{tabular}{|c|c|c|c|c|c|c|c|c|c|c|c|}
\hline & 总 & $\overrightarrow{8}$ & 苞 & $\stackrel{B}{0}$ & $\stackrel{\circ}{\circ}$ & 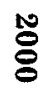 & ڤै & 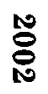 & ڤ్ & ڤั & : \\
\hline ASEAN & 8 & 8 & 8 & 7 & 7 & 7 & 6 & 7 & 6 & 6 & 6 \\
\hline China & 4 & 5 & 5 & 5 & 6 & 6 & 7 & 8 & 9 & 10 & 11 \\
\hline Japan & 14 & 13 & 12 & 11 & 11 & 11 & 10 & 9 & 9 & 8 & 7 \\
\hline $\begin{array}{l}\text { South } \\
\text { Korea }\end{array}$ & 4 & 3 & 3 & 3 & 3 & 3 & 3 & 3 & 3 & 3 & 3 \\
\hline
\end{tabular}

Source: U.N. Stat. Div. - Commodity Trade Statistics Database (COMTRADE), http://comtrade.un.org/db/ (last visited Oct. 14, 2009).

Since the early 1990 s, the United States has played a leading role in the Asian Pacific Economic Cooperation (APEC) Forum-the sole transregional framework for economic cooperation-and has had some success in discussing security and other noneconomic issues during APEC and other summits with leaders of the Asia Pacific region. The United States has decided to strengthen its economic interactions with East Asian economies other than China and Japan, and recently it has sought to sign bilateral FTAs with East Asian countries.

42. See Eng Chuan Ong, Anchor East Asian Free Trade in ASEAN, WaSH. Q., Spring 2003, at 60 (explaining that East Asia's share of U.S. trade is broadly comparable to U.S. NAFTA partners, and exceeds Western Europe's share). 
Table 7. U.S. FDI in East Asia (selected economies)

Unit: billion USD

\begin{tabular}{|c|c|c|c|c|c|c|c|c|c|c|c|}
\hline & 岁 & 象 & $\ddot{8}$ & $\bigotimes_{\infty}$ & 畐 & 8 & $\stackrel{n}{8}$ & 串 & 옹 & $\stackrel{8}{8}$ & ஓ् \\
\hline ASEAN 5 & 30 & 37 & 39 & 40 & 44 & 50 & 70 & 72 & 71 & 79 & 83 \\
\hline $\begin{array}{l}\text { Mainland } \\
\text { China } \\
\end{array}$ & 3 & 4 & 5 & 6 & 9 & 11 & 12 & 11 & 11 & 15 & 17 \\
\hline $\begin{array}{l}\text { Hong } \\
\text { Kong }\end{array}$ & 12 & 14 & 17 & 18 & 23 & 27 & 32 & 40 & 36 & 35 & 38 \\
\hline Japan & 37 & 35 & 34 & 41 & 55 & 57 & 56 & 66 & 58 & 68 & 75 \\
\hline Korea & 6 & 7 & 6 & 7 & 7 & 9 & 10 & 12 & 13 & 17 & 19 \\
\hline Taiwan & 4 & 4 & 5 & 6 & 7 & 8 & 9 & 10 & 12 & n.a. & 13 \\
\hline
\end{tabular}

Source: U.S. Dept. of Commerce, Bureau of Econ. Analysis, http://bea.gov/international/dilusdbal.htm (last visited Oct. 14, 2009).

\section{Notes:}

1. "ASEAN 5" includes Indonesia, Malaysia, the Philippines, Singapore, and Thailand;

2. The data for Indonesia from 2002-04 are not available.

The United States' most dramatic change in strategic adjustment in East Asia involves the improvement of Sino-U.S. relations. Since the end of the Cold War, U.S. strategy toward China has swayed between engagement and containment. ${ }^{43}$ After hesitation for more than a decade, the United States began to take a more balanced view of China's rise. Deputy U.S. Secretary of State Robert Zoellick articulated the U.S. vision of China as a responsible stakeholder in September 2005,

43. See Thomas Christensen, Posing Problems Without Catching Up: China's Rise and Challenges for U.S. Security Policy, INT'L SECURITY, Spring 2001, at 5; see also RICHARD BERnSTEIN \& Ross MUNRo, THE COMING CONFLICT WITH CHINA (1997) (predicting that China will become a global rival of the United States within the next two decades); Richard Bernstein \& Ross Munro, Coming Conflict with America, Foneign AfF., Mar.Apr. 1997, at 18; Peter T.R. Brookes, Strategic Realism: The Future of U.S.-Sino Security Relations, StRategic Rev., Summer 1999, at 53 (predicting that China will serve as a peer competitor with the U.S.); Denny Roy, Hegemony on the Horizon? China's Threat to East Asian Security, INT'L SECURITY, Summer 1994, at 149 (expressing concern about China's rise to power); but see RoberT S. Ross \& ANDREW J. NATHAN, THE GREAT WALL AND THE EMPTY FoRTRESS: CHINA's SEARCH FOR SECURITY (1997); Michael C. Gallagher, China's Illusory Threat to the South China Sea, INT'L SECURITY, Summer 1994, at 169 (concluding that China's military is persistently weaker than that of the United States and other world powers); Paul Godwin, The PLA Faces the Twenty-first Century: Reactions on Technology, Doctrine, Strategy, and Operations, in ChINA'S MnITARY FaCes THE FUTURE 39 (James R. Lilley \& David Shambaugh eds., 1999). 
reaffirming the U.S. commitment to engagement with China. ${ }^{44}$ Generally speaking, the Sino-U.S. relationship is now stabilized through bilateral channels, and engagement is the constructive path that provides a solid foundation for bilateral strategic interaction and multilateral dialogues.

\section{The FUtURE OF THE EAST ASIAN ORDER}

Today's East Asian order is characterized by economic integration, regional openness, intensive bilateralism and regionalism, provision of public goods by great powers, comparatively low levels of institutional development, and counterbalances to prevent the rise of regional hegemony. The stability of the existing order is not, however, guaranteed to last forever. In thinking about the future of the East Asian order, a number of uncertainties arise.

Although the power structure in East Asia is much more balanced than ever before, the process of economic integration has, so far, played the decisive role in building a constructive and stable order. Efforts to build political and security cooperation have not been as significant in the evolution of the current order. Economic integration may not, in the future, have such positive regional effects, as illustrated by the concern that the multiplication of FTAs will create an adverse "spaghetti effect" 45 for the regional economy and make further economic integration more difficult. Thus, more attention may be paid to the development of political and security arrangements.

In terms of security, there has been gradual change and reconstruction from hub-spoke arrangements to webs, with East Asian countries increasingly able to manage security problems through "shared regional norms, rising economic interdependence, and growing institutional linkages."46 On the other hand, the only security-specific process, the ARF, is simply a forum for discussion, not a formal security and defense cooperation arrangement. 47 The absence of such a security regime has not yet posed severe problems for East Asian countries, but

44. Robert B. Zoellick, Deputy U.S. Sec'y of State, Whither China: From Membership to Responsibility?, Address Before the National Committee on U.S.-China Relations (Sept. 21, 2005), available at http:/www.asiaing.com/whither-china-from-membership-toresponsibility.html.

45. "Spaghetti effect" is a term used to describe an entangled condition in which unpredictable dependencies occur among parties involved, frequently leading to coordination breakdowns and lapses in quality control.

46. Acharya, supra note 4.

47. See Chong Guan Kwa \& See Seng Tan, The Keystone of World Order, WaSH. Q., Summer 2001, at 95, 100 (asserting that the ARF is "a security forum, or 'talk shop,' not a defense arrangement"). 
the emergence of serious security threats would be a nightmare to address without better security arrangements and could become an obstacle to further regional integration.

Movement toward deeper security cooperation and institutionalization in East Asia, however, may be hampered by problems that flow from imbalances in the region. The first imbalance is revealed by the contrasting situations in Southeast Asia and Northeast Asia. Even with a wider cultural and ethnic diversity compared to Northeast Asia, Southeast Asia has already established a better community order. By contrast, the Northeast Asian countries, especially China, Japan, and South Korea, share more common cultural legacies, but they do not have a comparable sense of community among themselves and still face a traditional security dilemma similar to that between Japan and China. Market forces will likely continue to deepen the three economies' integration even without any further institutional efforts. But the solution to the security dilemma needs more ideas, innovation, political foresight, and strategic courage. A more stable order for East Asia will be hard to create without making progress on the security issues facing Northeast Asian countries.

The second imbalance appears in the roles that ASEAN, China, and Japan play in regional order building. Thus far, ASEAN has played a constructive leading role in regional order building, but its apprehensions about the ambitions of the great powers and the low level of institutionalization ASEAN nations favor indicate that East Asia needs another powerhouse for order building. Cooperation between China and Japan could be a constructive engine for regional order building. The two countries realize that neither of them could dominate in East Asia, but they have not yet shown a willingness to engage in more comprehensive cooperation on security issues.

The third imbalance concerns the bilateral relations between China, Japan, and ASEAN members. Until now, China and Japan have each set up bilateral cooperative frameworks with ASEAN that are based on common interests, the provision of regional and subregional public goods, and compromise on nonstrategic self-interests. China and Japan, on the other hand, have not taken any similar actions toward each other. This imbalance indicates that any political rift between China and Japan poses the most serious challenge to East Asian order building.

The Sino-Japanese relationship is at the center of these three imbalances. As one of the most complex relationships in the world, economic interdependence and security distrust coexist in bilateral relations between Japan and China. The two countries have formed reciprocal and win-win economic relations, and the overall ambiguity of 
their relationship does not check development of further economic interdependence. ${ }^{48}$ Japan's capital and technologies and China's market and economic potential are regarded as vital "special demands" for both countries. The close economic interdependence helps prevent any serious conflicts. Mistrust and distrust between the two countries remain, but their bilateral interdependence still grows.

However, in my view, since China and Japan are both attempting to rise in power and influence, strategic adjustments will be necessary, including creation of better security arrangements in East Asia. The change in Sino-Japanese relations since the second half of 2006 proves the correctness of this view. China and Japan have committed themselves to set up a bilateral strategic reciprocal relationship, and they have reached some consensus on the contents of this new strategic relationship:

- Support the counterpart's peaceful development to enhance bilateral political trust;

- Deepen reciprocal cooperation to reach common development;

- Strengthen defense dialogue and communication to safeguard and promote regional stability;

- Intensify human exchanges to enhance the mutual understanding and friendly feelings between Chinese and Japanese people; and

- Strengthen coordination and cooperation to meet regional and global challenges together.

The two governments have also decided to enhance cooperation in energy, environmental protection, agriculture, medicine, information technologies, and other fields, and to cooperate in dealing with both regional and global problems. The development of these more intense bilateral relations provides new dynamics and opportunities for common interest convergence in the region and, thus, potential regional order building through greater institutionalization.

The new mode of Sino-Japanese bilateral relations can also support existing East Asian institutional frameworks, such as ten-plus-three, ARF, and the East Asia Summits, all of which previously resulted from common interest convergence and varying degrees of institutionalization. Among those frameworks, the ARF is the only one focused on security, and that is expected to work as a confidencebuilding measure, thus decreasing the risk of escalating security dilemmas and promoting cooperative security. The East Asia Summit is

48. See Thomas J. Christensen, Fostering Stability or Creating a Monster? The Rise of China and U.S. Policy toward East Asia, INT'L SECURITY, Summer 2006, at 81, 88-89 (explaining that while Japan has long been China's largest trading partner, the economic relationship between the two countries is now reciprocal). 
the only super-regional framework, but East Asian countries have different views on its functions, so it could fail to play a leading role in dealing with regional issues. The ten-plus-three process is regarded as the primary channel in pushing forward East Asian integration, and East Asian states will continue to promote cooperation in the spirit of openness, tolerance, and mutual success. In light of these realities, strategic cooperation between and among the three Northeast Asian countries-China, Japan, and South Korea-will be key to the development of a future region-wide order for East Asia.

In a sense, China and Japan are ready for regional order building, although they compete for regional leadership. The two countries are active in regional cooperative frameworks, and they have been implementing additional proposals of regional cooperation. Japan and China increasingly realize that fierce competition restricts their strategic interests and that moving towards a stronger bilateral cooperative framework based on common interests would be the feasible route to solve existing imbalances and advance regional order building. All things considered, Japan and China have an unprecedented opportunity to advance East Asian order and stability through expanding their common interests and engaging in deeper institutionalization of their relationship.

\section{A COMMON INTERESTS-BASED STRATEGIC FRAMEWORK FOR SINO-JAPANESE RELATIONS}

The Sino-Japanese relationship is very complex, featuring a long history of friendly relations and deep strategic distrust and mistrust. Both countries have recently realized that they must address their bilateral issues within a broader regional and global perspective. The transformation of East Asia as a region, made possible by the impact of regional integration and globalization, provides the necessary conditions for positive development of Sino-Japanese relations. Moving forward, Japan and China should work to develop a bilateral strategic framework built on convergence of common interests and better institutionalization of the East Asian order.

\section{A. The Complex Sino-Japanese Relationship}

As one of the most complex bilateral relationships in the world, Sino-Japanese relations affect not only the two countries themselves, but also the entire East Asian region and the whole world. Historical legacies, political mistrust, and security distrust lead to complex dilemmas between China and Japan. Conversely, close economic 
cooperation and common security concerns indicate that interdependence between the two countries also exists. In this relationship, complexity contains both negative and positive aspects.

Although there are 236 sister-city agreements between China and Japan and human traffic between the countries is significant (more than 5.5 million persons in 2008), historical legacies still weigh heavy on the minds of the Chinese and Japanese people, which is reflected in fragile sentiments and complicated public opinions in both China and Japan.

Economic interdependence between China and Japan has been enhanced, and the two countries enjoy ever-closer economic ties. Their bilateral trade volume in 2008 reached U.S.\$266.78 billion, and Japan's investment in China was U.S.\$65.38 billion by the end of 2008, second only to Hong Kong. The cumulative total of Japan's overseas development assistance to China from 1979 to 2007 reached to 288.89 trillion Yen, and 41,162 Japanese projects were implemented in mainland China by the end of 2008.49 In a word, Japan has been and continues to be an indispensable source of China's capital, technology, and, to a lesser extent, an export outlet.

China's economic rise provides Japan with even more opportunities. China today is the leading exporter of products to Japan and the second largest destination for Japanese exports. China's economic development has so far played a positive role in the recent revival of Japan's economic growth, demonstrating the codevelopment that is achieved in their bilateral economic relations. Such interdependence would be costly to discontinue for either side and acts as a deterrent to severe conflict.

Yet, in political and security terms, both countries have been beset by antagonisms and deep-seated suspicions, which magnify the implications of run-of-the-mill disputes, such as those involving the Diaoyu Islands and the East China Sea. Bilateral relations are often mixtures of hot economics and cold politics, and Sino-Japanese relations exhibit this mixture. In the broader picture, although distrust remains, bilateral interdependence continues to grow, and the two governments are showing a desire to see an improvement in their bilateral relations. Accordingly, to portray Sino-Japanese relations as a zero-sum game would be misleading, and any account that does not account for the de facto economic interdependence and political adjustments already made between Japan and China would be myopic.

In dealing with regional affairs, China's and Japan's respective desires for a larger role have become principal catalysts in shaping a

49. See Ministry of Foreign Aff., China's Relations with Japan, http://www.fmprc.gov. cn/chn/pds/gihdq/gi/yz/1206_25/sbgx/ (P.R.C.) (last visited Oct. 29, 2009). 
new order in East Asia. Japan worries about possible Chinese dominance of East Asia, while China worries that the strategic ties between the United States and Japan will impair its ability to achieve key national interests. Regional institutions, therefore, can play a catalytic role in maximizing gains from economic exchange and helping diffuse mistrust in the security arena. In other words, regional cooperative frameworks could provide wide channels for Sino-Japanese bilateral coordination and dialogue.

Most countries in the region expect the improvement of SinoJapanese relations, which would then be a driving force for further regional cooperation. China and Japan realize that dominance by any single country would not be welcomed in East Asia. Thus, the most effective way to safeguard their vital national interests is to act as the stakeholders in the region and play responsible roles within the regional frameworks. Competition between the two cannot be avoided all the time, and win-win results will not always be reached in bilateral relations. Nevertheless, Japan and China have growing opportunities to avoid the type of zero-sum outcomes that lead to political problems and potential conflicts.

\section{B. Common Interests Between China and Japan}

China and Japan are in the process of making mutual adjustments. Many strategists predict that the next ten years will be the moment of truth for Sino-Japanese relations. The best outcome would be establishment of a comprehensive framework for coordination and cooperation, with strategic trust at the center. Given the complexity of Sino-Japanese relations, the practical measure to take is to set up a strategic framework based on common interests, and hopefully strategic trust would be produced through the framework, step by step.

Japanese prime minister Shinzo Abe proposed building a relationship of strategic reciprocity with China shortly after he took office in September 2006. It was the first time that a Japanese leader used the word "strategic" to describe Sino-Japanese relations, and many experts regarded it as a great turn in Japan's policy toward China. In the spring of 2007, Chinese premier Wen Jiabao paid an official visit to Japan, during which the two governments reached important consensus on the content of their new strategic relations. In my understanding, this bilateral relationship of strategic reciprocity means a reciprocal relationship based on common strategic interests-a comprehensive, long term, and stable bilateral relationship that moves beyond limited, tactical cooperation. 
Table 8. A Common Interests-Based Strategic Framework for Sino-Japanese Relations

\begin{tabular}{|c|c|c|}
\hline & National Level & Bilateral Level \\
\hline $\begin{array}{l}\text { Political } \\
\text { Dimension }\end{array}$ & $\begin{array}{l}\text { Nonindependence of Taiwan; To } \\
\text { cooperate in efforts to ensure that } \\
\text { cross-strait relations do not } \\
\text { escalate tensions; } \\
\text { Both adhere to the road of } \\
\text { peaceful development. }\end{array}$ & $\begin{array}{l}\text { To enhance political coordination } \\
\text { via certain mechanisms; } \\
\text { To keep routine exchange visits of } \\
\text { top leaders. }\end{array}$ \\
\hline $\begin{array}{l}\text { Economic } \\
\text { Dimension }\end{array}$ & $\begin{array}{l}\text { China manages to keep macro- } \\
\text { economic stability. }\end{array}$ & $\begin{array}{l}\text { To facilitate bilateral trade and } \\
\text { investment; } \\
\text { To expand and utilize bilateral } \\
\text { economic complementarities for } \\
\text { further economic cooperation. }\end{array}$ \\
\hline $\begin{array}{l}\text { Security } \\
\text { Dimension }\end{array}$ & & $\begin{array}{l}\text { To maintain and strengthen } \\
\text { bilateral strategic dialogues; } \\
\text { To enhance exchanges between } \\
\text { bilateral military circles. }\end{array}$ \\
\hline $\begin{array}{l}\text { Cultural } \\
\text { Dimension }\end{array}$ & & $\begin{array}{l}\text { To push forward study on } \\
\text { historical issues so to prevent } \\
\text { historical issues from hindering } \\
\text { present relations; } \\
\text { To enhance cultural exchanges } \\
\text { and mutual understanding. } \\
\end{array}$ \\
\hline $\begin{array}{l}\text { Social } \\
\text { Dimension }\end{array}$ & & $\begin{array}{l}\text { To enhance nongovernmental } \\
\text { interaction such as tourism and } \\
\text { academic and youth exchanges, } \\
\text { laying solid foundations for } \\
\text { bilateral relations. }\end{array}$ \\
\hline
\end{tabular}




\begin{tabular}{|c|c|c|}
\hline & Regional Level & Global Level \\
\hline $\begin{array}{l}\text { Political } \\
\text { Dimension }\end{array}$ & $\begin{array}{l}\text { To coordinate in regional political } \\
\text { dialogues and cooperation; } \\
\text { To coordinate to maintain } \\
\text { regional cooperation and its main } \\
\text { features as openness, inclusivity } \\
\text { and progressiveness. }\end{array}$ & $\begin{array}{l}\text { To set up dialogue mechanisms on } \\
\text { global issues of common concern } \\
\text { and take an open attitude on the } \\
\text { issues vital to the core interest of } \\
\text { the other side. }\end{array}$ \\
\hline $\begin{array}{l}\text { Economic } \\
\text { Dimension }\end{array}$ & $\begin{array}{l}\text { To push forward regional and } \\
\text { subregional (China, Japan, and } \\
\text { South Korea) trade and } \\
\text { investment; } \\
\text { To maintain regional } \\
\text { macroeconomic and financial } \\
\text { stability; } \\
\text { To facilitate financial market } \\
\text { development. }\end{array}$ & \\
\hline $\begin{array}{l}\text { Security } \\
\text { Dimension }\end{array}$ & $\begin{array}{l}\text { To resolve and prevent regional } \\
\text { conflicts on the Korean Peninsula; } \\
\text { To cooperate in subregional } \\
\text { energy security by protecting the } \\
\text { common petroleum transit; } \\
\text { To cooperate in dealing with } \\
\text { various nontraditional security } \\
\text { problems. }{ }^{1]}\end{array}$ & $\begin{array}{l}\text { To resolve and prevent regional } \\
\text { conflicts on the Korean Peninsula; } \\
\text { To cooperate in dealing with state } \\
\text { failure; } \\
\text { To cooperate in dealing with } \\
\text { various nontraditional security } \\
\text { problems. } .^{[1]}\end{array}$ \\
\hline $\begin{array}{l}\text { Cultural } \\
\text { Dimension }\end{array}$ & $\begin{array}{l}\text { To push forward study on } \\
\text { historical issues among China, } \\
\text { Japan and South Korea. }\end{array}$ & \\
\hline $\begin{array}{l}\text { Social } \\
\text { Dimension }\end{array}$ & $\begin{array}{l}\text { To enhance nongovernmental } \\
\text { interaction such as tourism and } \\
\text { academic exchanges. }\end{array}$ & \\
\hline
\end{tabular}

[1] Nontraditional security problems include, but are not limited to: terrorism; preventing transnational crime, such as drug trafficking, piracy, money laundering, and corruption; human security issues like aging, communicable disease control, environmental protection, and natural disaster response; and clean energy. 
A key challenge in making this strategic reciprocity work is to define common interests between China and Japan. The central task for Chinese and Japanese decision makers is to define expectations for the future of Sino-Japanese relations in the context of globalization and regionalization. The agenda for such a relationship must be defined more broadly and strategically than simply returning to the issues of Japan's historical legacies, the Taiwan issue, and Chinese nationalism. ${ }^{50}$ It requires adding other regional and global concerns. In sum, Sino-Japanese strategic reciprocal relations must be centered on common interests that address bilateral concerns, regional challenges, and global issues. Table 8 summarizes the basic common interests between the two countries and indicates that the convergence and institutionalization of regional common interests are vital to the bilateral strategic framework (see Table 8 on previous pages).

In the above strategic framework, the national and bilateral levels should be regarded as where the basic interests reside, which reflects the importance of bilateral reciprocity. The regional level should be the center of the framework, meaning that common interests are not based only on the pursuit of reciprocal benefits, but also on dealing with common threats together. The global level should reflect the strategic vision of these two great powers, and the openness of East Asian regionalism should allow the two countries to consider global interests in decision making and framework design.

The above bilateral, common interests-based strategic framework is an ideal type, which would need to be adjusted and expanded with the development of Sino-Japanese relations. In other words, when we analyze common interests in the bilateral relationship, we should focus not only on the structural aspects, which would be the foundation for bilateral relations, but also on the process elements, which would, over time, become more important in the future of Sino-Japanese relations.

However, there are undeniable zero-sum factors in Sino-Japanese relations, such as historical legacies and the disputes over the Diaoyu Islands and the East China Sea. Disputes and conflicts always coexist with cooperation and pursuit of common interests in bilateral and multilateral relations. This dynamic should be regarded as the dialectic of contemporary international relations. Disputes and conflicts should not stand in the way of the pursuit of common interests, and the mitigation and reasonable resolution of disputes and conflicts will, of course, enhance the promotion of common interests.

50. See Scott Snyder, Introduction: Prospects for a China-Japan-U.S. Trilateral Dialogue, in NEW DIMENSIONS OF CHINA-JAPAN-U.S. RELATIONS 11, 19-20 (Japan Ctr. for Int'l Exchange ed., 1999) (citing the importance of identifying issues of mutual interest in the context of Sino-Japanese dialogue). 


\section{Feasible Strategic Measures to Pursue}

China's and Japan's respective cooperation with ASEAN indicate that both countries have accumulated rich experiences in building strategic frameworks through common interest convergence and institutionalization. The White Paper on the "Peaceful Development Road of China," as well as recent speeches by top Chinese leaders, show that China wants to enhance cooperation with neighboring countries based on common interests. ${ }^{51}$ Accordingly, a combination of pragmatic accommodation, normative convergence, economic interaction, and some strategic hedging currently takes place between China and most of its neighbors. As Shambaugh observed, "China and ASEAN are forging a productive and lasting relationship that is gradually erasing a history built on widespread suspicion, painful memories, and lingering tensions." 52

As Ryosei Kokubun points out, Japan's reemergence and China's development support each other, yet genuine understandings on many issues are missing between the two countries. In principle, the main route for improving Sino-Japanese relations is to bring bilateral coordination efforts into the processes of East Asian order building, thus enhancing bilateral strategic reciprocity in both regional and global arenas. In practice, to transcend the present mistrust and misperception, the two countries first need to make more determined efforts to understand the changes taking place within the other country and to engage in policy responses that can lead to mutual understanding and trust. Second, the two countries could take measures to build bilateral, institutionalized trust through transparency, strategic dialogues, and other confidence-building measures. Third, the two countries could pursue measures to set up a consulting mechanism for use in dealing with multilateral issues of mutual concern.

\section{CONCLUSION}

The convergence and institutionalization of common interests can provide a workable way to build a constructive East Asian regional order. East Asia has a long history of attempts to establish order in the region. Today, East Asian countries embrace both globalization and regionalization, and they are beginning to think more seriously about the future regional order framework. Regional integration and its

51. Mori Kazuko, East Asia Community and China, INT'L AFF., May 2006, at 4.

52. Shambaugh, supra note 35, at 76 (citing Alice D. Ba, China and ASEAN: Reinvigorating Relations for the 21st Century, ASIAN SURVEY, July-Aug. 2003, at 622). 
spillover effects, China's comprehensive and peaceful rise, Japan's political pursuit of a greater role in both regional and world arenas, ASEAN's influence, and the United States' strategic adjustments in the region are the main dynamics in East Asian order formation. These dynamics in turn determine not only the openness of the regional order but also the processes and roadmap for continued order building. East Asia has established or participates in useful institutional frameworks at subregional, regional, and super-regional levels, all of which advance common interest convergence and institutionalization.

Foresight tells us that Sino-Japanese relations are crucial to the future of East Asia order. China and Japan appear increasingly ready for more regional order building, but they realize that their fierce competition restricts their strategic interests. Setting up a bilateral cooperative framework based on their common interests would be the only feasible route. The existing strategic reciprocal relationship between China and Japan mainly deals with bilateral relations, especially how to stabilize the bilateral relationship. The next steps are to connect this bilateral strategic reciprocal relationship with other regional strategies, thus forming an overall common interest framework for East Asia. Moving in this direction would represent progress in East Asian order formation.

For China and Japan, this vision is not only a great challenge, but it is also an unprecedented opportunity. Great nations must think before they act. It is high time for China and Japan to begin thinking more clearly about their interests and responsibilities nationally, regionally, and globally and to act on strategic choices that benefit their people, Asia, and the entire world. 